\title{
Gender Estimation from Angular Parameters of Mandible in Turkish Adults
}

\section{Türk Yetișkinlerde Mandibula Açısal Parametrelerinden Cinsiyet Tahmini}

\section{Seda SERTEl MEYVACI ${ }^{1}$ (D), Duygu GÖlleR BULUT² $\mathbb{D}^{\mathbb{D}}$, Ayșe Tuğçe ÖZTÜRK KOÇAK² (D), Handan ANKARALI ${ }^{3}$}

${ }^{1}$ Bolu Abant Izzet Baysal University, Faculty of Medicine, Department of Anatomy, Bolu, Turkey

${ }^{2}$ Bolu Abant Izzet Baysal University, Faculty of Dentistry, Department of Oral and Maxillofacial Radiology, Bolu, Turkey ${ }^{3}$ Istanbul Medeniyet University, Faculty of Medicine, Department of Biostatistics and Medical Informatics, İstanbul, Turkey

ORCID ID: Seda Sertel Meyvaci 0000-0002-9450-145X, Duygu Göller Bulut 0000-0003-4260-2520,

Ayșe Tuğçe Öztürk Koçak 0000-0002-2728-5793, Handan Ankarali 0000-0002-3613-0523

Cite this article as: Sertel Meyvacı S et al. Gender estimation from angular parameters of mandible in Turkish adults. Med J West Black Sea. 2021;5(2):240-247.

Corresponding Author

Seda Sertel Meyvaci

E-mail

sedasertelmeyvaci@gmail.com

\begin{abstract}
Aim: In this study, it was aimed to evaluate the effect of angular parameters, which are a part of mandibular morphometry, on gender assessment with the help of cone beam computed tomography (CBCT).
\end{abstract}

Material and Methods: A total of 197 healthy adults, 100 females and 97 males, aged between 1868 years were included in our study. Ten angular parameters of the mandible were evaluated using CBCT. Independent samples t-test was used to compare the gender for each of the age and angle measurements. In addition, the success of the angles in gender diagnosis was examined by a stepwise linear canonical differential analysis. Statistical significance level was accepted as $p<0.05$.

Results: When we compare mandible angular parameters and age measurements between gender groups, left Go angle $(p=0.026)$, mentomandibular angle $(p=0.007)$, right $\beta$ angle $(p=0.002)$, right $a$ angle $(p=0.001)$, left $a$ angle $(p=0.009)$ and age $(p=0.014)$ values differed significantly, and the remaining 5 angles were similar ( $p>0.05)$. In order to eliminate the effect of age difference, a total of 11 variables including age were comprised in the model, and discriminant analysis was performed with the stepwise variable elimination method to select only the variables that could make significant gender discrimination. As a result of variable elimination, we found that the overall correct classification success of the discriminant function, which includes a total of 4 angles, sexually dimorphic right a angle, left Go angle, right $\beta$ angle, and left $\alpha$ angle, was $71.5 \%$.

Conclusion: This study showed that among the angular parameters of the mandible, the left Go angle being the highest, the right $a$ angle, right $\beta$ angle and left $a$ angles have sexual dimorphic properties, and gender estimation can be made with $71.5 \%$ overall accuracy with the discriminant function containing these parameters.

Keywords: Angular parameters, Cranium, Gender, Mandible, Tomography

öz

Amaç: Bu çalışmada, mandibula morfometrisinin bir parçası olan açısal parametrelerinin cinsiyet belirlemedeki etkisinin konik ışınlı bilgisayarlı tomografi (KIBT) yardımı ile değerlendirmesi amaçlanmıştır.

Gereç ve Yöntemler: Araştırmamıza yaşları 18-68 yaş arasında olan 100 kadın ve 97 erkek olmak üzere toplam 197 sağlıklı yetişkin birey dahil edildi. Mandibulaya ait 10 tane açısal parametre KIBT yardımıyla değerlendirildi. Yaş ve açı ölçümlerinin her biri açısından cinsiyetlerin karşılaştırılmasında 
bağımsız örneklem t-testi kullanıldı. Bunun yanı sıra açıların cinsiyet tanısındaki başarıları adımsal doğrusam kanonik ayrım analizi ile incelendi. İstatistiksel anlamlılık düzeyi olarak $p<0,05$ kabul edildi.

Bulgular: Mandibula açısal parametrelerinin ölçümlerini ve yaşı cinsiyet grupları arasında karşılaştırdığımızda, sol Go açı ( $p=0,026)$, mentomandibular açı $(p=0,007)$, sağ $\beta$ açı $(p=0,002)$, sağ a açı $(p=0,001)$, sol a açısı $(p=0,009)$ ve yaş $(p=0,014)$ değerinin anlamlı farklılık gösterdiği geriye kalan 5 açının benzer olduğu görüldü ( $p>0,05$ ). Yaş farklılığının etkisini gidermek için yaş dahil toplam 11 değişken modele alınarak sadece anlamlı düzeyde cinsiyet ayrımı yapabilen değişkenlerin seçilmesi ve stepwise değişken eleme yöntemi ile birlikte diskriminant analizi yapıldı. Değişken elemesi sonucunda, cinsel dimorfik bulunan sağ a açı, sol Go açı, sağ $\beta$ açı, sol a açı olmak üzere toplam 4 açı içeren diskriminant fonksiyonunun genel doğru sınıflama başarısını \% 71,5 olarak bulundu.

Sonuç: Bu çalışma mandibulanın açısal parametreleri arasında sol Go açının en yüksek olmak üzere sağ a açı, sağ $\beta$ açı, sol a açılarının cinsel dimorfik özelliğe sahip olduğunu ve bu parametreleri içeren diskriminat fonksiyonu ile \% 71,5 doğruluk oranı ile cinsiyet tahmini yapılabileceğini göstermiştir.

Anahtar Sözcükler: Açısal parametreler, Cinsiyet, Kraniyum, Mandibula, Tomografi

\section{INTRODUCTION}

Forensic identity is mainly based on the study of anthropometric characters of skeletal remains $(1,2)$. Gender determination is often the first step in the identification process and plays an important role in identifying human remains as it reduces the probability of identification by $50 \%(3,4)$. Human skeletal components play an important role in gender determination, forensics, anthropology and archelogy (5-7).

In order to contribute to the gender determination process, studies have been conducted in different populations to evaluate many morphometric criteria in skeletal bones (3, 7). In previous studies, we found that a lot of research has been done due to the specific anatomical features of the mandible bone. When we examined research methods, we saw that it was performed directly on dry bone using caliper or with the help of radiological imaging methods (8-10).

Due to the hard structure of the mandible bone, it is the largest facial bone that usually resists post-mortem damage and constitutes an important source of personal identification (11). Due to this important position on the face, the mandible bone, which is aesthetic, sexually dimorphic and very easy to recognize, has many angular features $(12,13)$.

With Cone Beam Computed Tomography (СВCT) systems, it is possible to obtain axial, coronal and sagittal multiplane images of maxillofacial structures as well as 3D reconstructions and traditional image projections such as panoramic and cephalometric without magnifications (14). CBCT has advantages such as sub-millimetric voxel resolution, lower radiation dose, and easy editing and viewing of three-dimensional images on personal computers $(15,16)$. In addition, measurements made on CBCT images are highly close to actual values $(17,18)$.

Although there are studies examining the angular parameters of the mandible, there are limited studies on gender determination. The aim of this study is to evaluate the effect of angular parameters, which are a part of mandibular morphometry, on gender determination via CBCT.

\section{MATERIALS and METHODS}

This study was carried out in Bolu Abant Izzet Baysal University, Faculty of Dentistry, Department of Oral and Maxillofacial Radiology. Ethical permission was obtained from Bolu Abant İzzet Baysal University Clinical Research Ethics Committee for the study with the decision number 2020/83. During the execution of the study, the principles defined in the Declaration of Helsinki were followed.

In order to constitute the sample group in the study, the archive of patients who were diagnosed with TMD after clinical and radiographic examination between 2017-2019 in the dentomaxillofacial radiology clinic and who had CBCT for detailed evaluation were scanned. The study included images of patients over the age of 18 who did not have dental malocclusions, including the entire maxilla, mandible and all the bone margins that would allow relevant measurements to be made. Images containing artefacts and any pathology affecting the mandibular parameters were excluded from the study. Finally, a total of 197 individuals, 100 females (mean age $29.15 \pm 13.45$ years) and 97 males (mean age $25.22 \pm 8.02$ years) were included in the study. Ten angular parameters of the mandible were evaluated using CBCT.

\section{CBCT Procedures}

CBCT images were gained using the $\mathrm{i}-\mathrm{CAT}$ 3D Imaging System (Imaging Sciences International, Hatfield, PA, USA). All images were scanned with the same exposure parameters (120 kVp, $7 \mathrm{~mA}, 4.8 \mathrm{sec}$. scan time, $0.3 \mathrm{~mm}^{3}$ voxel size, and 10-13x16 mm field of view (FOV). Images were combined with i-CAT Vision 1.9 software program (Imaging Sciences International LLC, Hatfield, PA, USA). The raw data of the images were transferred to the personal computer. All the images were evaluated with the same computer (Lenovo Legion Y520 laptop computer with $1920 \times 1080$ pixel resolution, 15.6 inch monitor, 7th generation Intel® ${ }^{\circledR}$ Core $^{\mathrm{TM}}$ i7 and i5 processor). A sole maxillofacial radiologist were reviewed all the images. A two-step controlled measurement was per- 


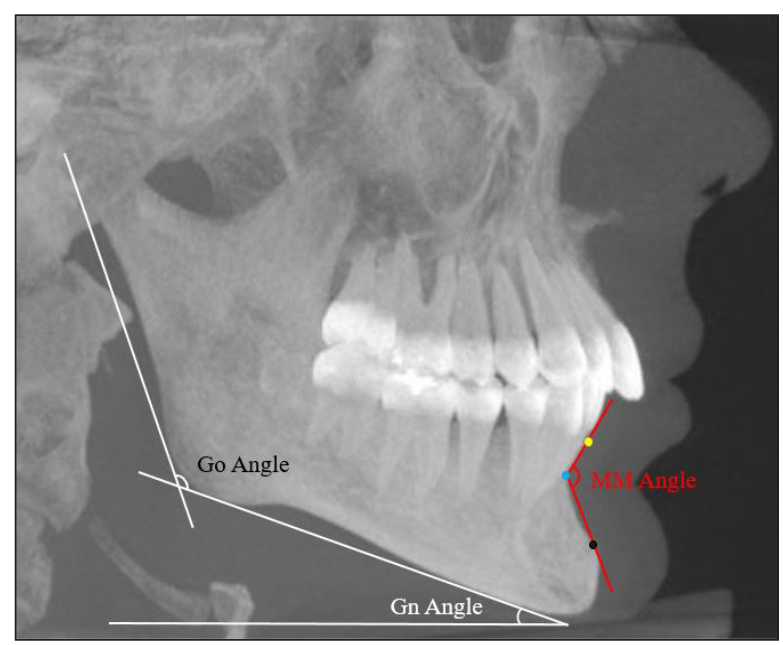

Figure 1: Right lateral view, Gonion angle, Gnathion angle, Mentomandibular angle (MM Angle). Yellow dot is Infradentate point, blue dot is $\mathrm{B}$ point, black dot is Pogonion point.

formed for each parameter, and the age and gender of each patient were also recorded.

\section{Measurements}

Ten angles of the mandible of the cases were measured, and 7 different anatomical points were taken into consideration in the measurement of angle parameters: Gonion (Go), Gnathion (Gn), Infradentale (Id), Pogonion (Pg) and Condylion (Co). Go, $a$ and $\beta$ angles in the mandible were measured bilaterally.

- Go angle: The angle between the posterior border of mandibular line and lower border of mandibular line (Figure 1)

- Gn angle: The angle between lower border of mandibular line and transverse axis (Figure 1).

- Mentomandibular (MM) angle: The angle between Id and $\mathrm{Pg}$ anatomic points of mentomandibular area (Figure 1)

- a angle: The angle between Co-Go line and Co-Gn line in Co-Go-Gn triangle (Figure 2).

- $\quad \beta$ angle: The angle between Go-Gn line and $\mathrm{Gn}-\mathrm{Co}$ line in Co-Go-Gn triangle (Figure 2).

- Co-Co angle: The angle between right mandibular condyle line - left mandibular condyle line (Figure 3).

\section{Sample Size}

Considering both literature review and our study's hypothesis, using the hypothesis that there will be a moderate effect size between the two groups and the significance test of the difference between the two averages, Prior power is accepted as $80 \%$ and Type-l error is $5 \%$ for the effect size $w=0.50$.
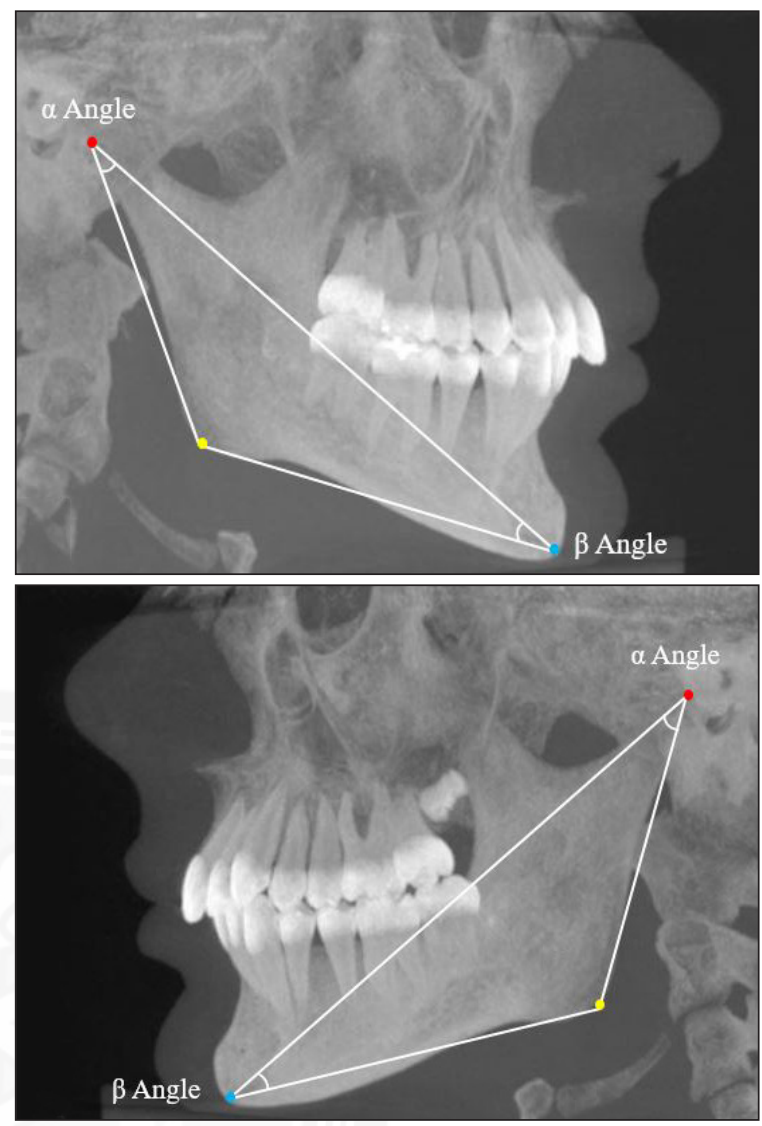

Figure 2: Right and left lateral view, $\alpha$ and $\beta$ angle. Red dot is Condylion point, yellow dot is Gonion point, blue dot is Gnathion point.

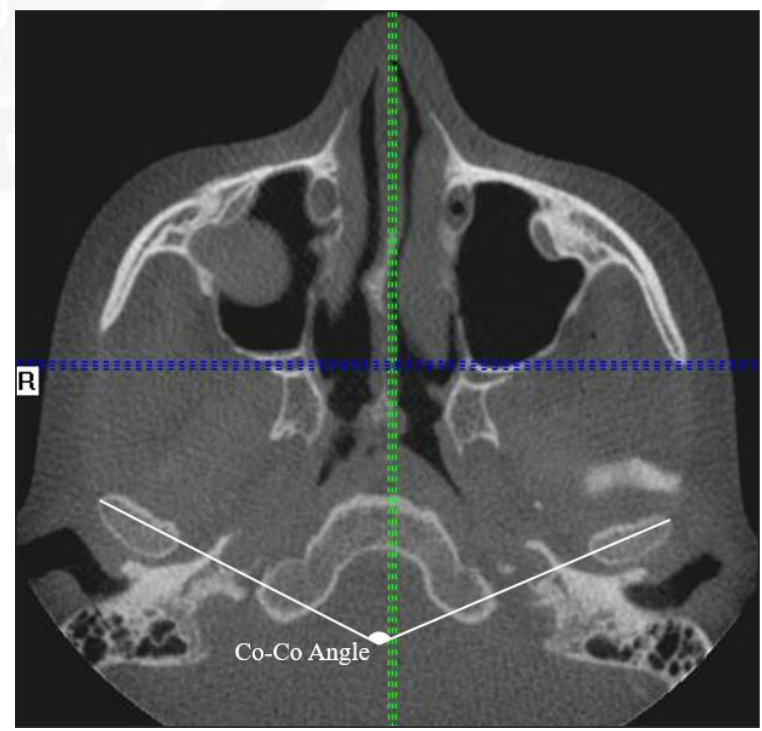

Figure 3: Axial section, Co-Co angle: The angle between lines passing through the center of the condyles. 
It was determined that there should be at least 93 people in each group, at least 186 in total. G Power 3.1 program was used for sample size determination.

\section{Statistical Analysis}

Descriptive values of the obtained data were calculated as number and \% frequencies, mean \pm standart deviation and given in tables. The conformity of age and angles to the normal distribution was examined using the Kolmogorov-Smirnov test. In addition, independent samples t-test was used to compare the gender in terms of age and angle measurements. In addition, the success of the angles in gender diagnosis was examined by stepwise linear canonical discriminant and ROC analysis. $p<0.05$ was accepted as the statistical significance level and SPSS (ver. 23) program was used in calculations.

\section{RESULTS}

In the study, 10 angular parameters of 100 female and 97 male mandible bones were measured. It was determined that these measurements showed normal distribution in both genders. The female and male comparison results for each of the measurements made from the mandible bones are given in Table 1.

When angle measurements are taken one by one, in the left Go $(p=0.026)$ angle, in MM angle $(p=0.007)$, in right $\beta$ angle $(p=0.002)$, in right $a$ angle $(p=0.001)$, and in left $a$ angle $(p=0.009)$ it was observed that there was a significant difference between the genders, and the genders were similar in terms of the remaining 5 angles ( $p>0.05$ ). In addition, it was determined that the mean ages also differed significantly between gender groups $(p=0.014)$.

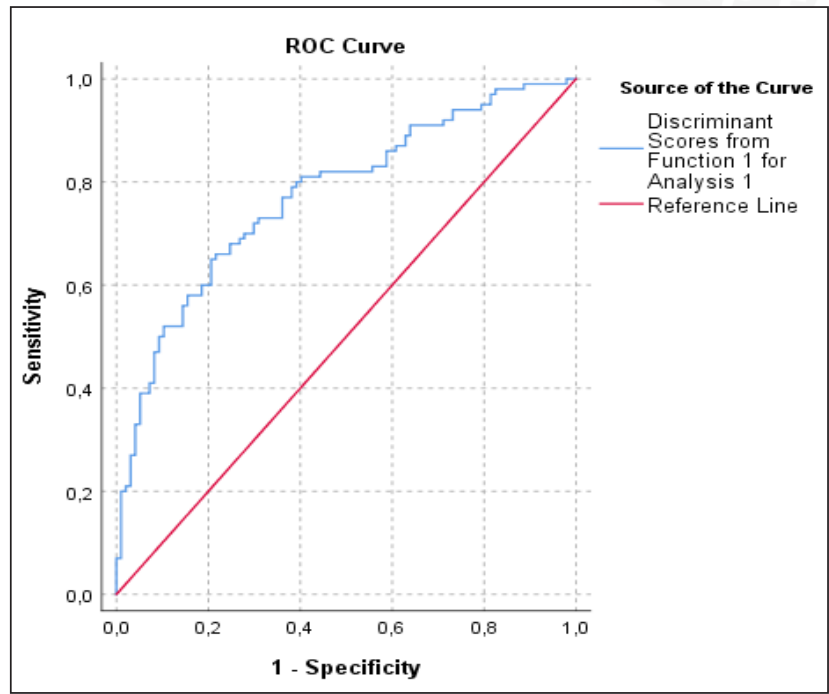

Figure 4: Gender diagnosis success of linear discriminant function including four angle measurements
In order to eliminate the effect of age difference, a total of 11 variables including age were taken into the model and discriminant analysis was performed again with the stepwise variable elimination method in order to select only variables that can make significant gender discrimination and to find a discriminant function containing these variables, and the results shown in Table 2 were obtained.

As a result of variable screening, the features that have a significant effect on gender discrimination were found as right $\alpha$ angle, left Go angle, right $\beta$ angle and left $\alpha$ angle.

Standardized coefficients of the obtained discriminant function are given in Table 2 .

With the help of the coefficients given in Table 2, after the measurements values of a new individual are standardized, the result will be correctly estimated at a rate of $71.6 \%$ when the following function is replaced. The discriminant function consisting of standardized model coefficients is defined below.

Table 1: Comparison of all measurements by gender

\begin{tabular}{|c|c|c|c|c|c|}
\hline & Gender & $\mathbf{n}$ & Mean & SD & $\mathbf{p}$ \\
\hline \multirow{2}{*}{ Age } & Male & 97 & 25.22 & 8.02 & \multirow{2}{*}{0.014} \\
\hline & Female & 100 & 29.15 & 13.45 & \\
\hline \multirow{2}{*}{ Right Go Angle } & Male & 97 & 125.59 & 8.07 & \multirow{2}{*}{0.543} \\
\hline & Female & 100 & 124.92 & 7.17 & \\
\hline \multirow{2}{*}{ Left Go Angle } & Male & 97 & 124.96 & 7.28 & \multirow{2}{*}{0.026} \\
\hline & Female & 100 & 127.32 & 7.47 & \\
\hline \multirow{2}{*}{ Gnathion Angle } & Male & 97 & 22.55 & 6.47 & \multirow{2}{*}{0.093} \\
\hline & Female & 100 & 21.13 & 5.24 & \\
\hline \multirow{2}{*}{ MM Angle } & Male & 97 & 143.30 & 8.33 & \multirow{2}{*}{0.007} \\
\hline & Female & 100 & 140.01 & 8.58 & \\
\hline \multirow{2}{*}{ Right $\beta$ Angle } & Male & 97 & 24.63 & 3.99 & \multirow{2}{*}{0.002} \\
\hline & Female & 100 & 26.35 & 3.83 & \\
\hline \multirow{2}{*}{ Left $\beta$ Angle } & Male & 97 & 25.54 & 4.46 & \multirow{2}{*}{0.214} \\
\hline & Female & 100 & 26.29 & 3.90 & \\
\hline \multirow{2}{*}{ Right a Angle } & Male & 97 & 30.11 & 4.25 & \multirow{2}{*}{0.001} \\
\hline & Female & 100 & 32.36 & 4.92 & \\
\hline \multirow{2}{*}{ Left a Angle } & Male & 97 & 30.39 & 3.98 & \multirow{2}{*}{0.009} \\
\hline & Female & 100 & 31.94 & 4.26 & \\
\hline \multirow{2}{*}{ Co-Co Angle } & Male & 97 & 136.21 & 12.35 & \multirow{2}{*}{0.450} \\
\hline & Female & 100 & 134.83 & 13.12 & \\
\hline \multirow{2}{*}{ Go-Gn-Go Angle } & Male & 97 & 76.43 & 5.33 & \multirow{2}{*}{0.480} \\
\hline & Female & 100 & 75.85 & 6.08 & \\
\hline
\end{tabular}

SD: Standart Deviation

Table 2: Standardized Canonical Discriminant Function Coefficients

\begin{tabular}{lc}
\hline Variables & Standardized Coefficients \\
\hline Left Go Angle & 1.127 \\
\hline Right $\beta$ Angle & 0.529 \\
\hline Right a Angle & 0.418 \\
\hline Left a Angle & 0.648 \\
\hline
\end{tabular}


Linear Discriminant model for four variables were included;

Gender (Female / Male) $=1.127$ (left Go angle) +0.529 (right $\beta$ angle) +0.418 (right $a$ angle) +0.648 (left $a$ angle)

When the coefficients are examined, the highest value is 1.127 and belongs to the left Go angle. In addition, all coefficients are positively signed, meaning they were higher in female. In this case, it is seen that the angle measurement whose effect is significant and the most successful in distinguishing male and female is the "left Go angle" and the least successful angle measurement is the "right a angle". Since the effect of other angle measurements on gender discrimination was not found to be significant, it was excluded from the model.

According to the standardized scores, the group Centroids values of male and female are 0.513 and -0.529 , respectively.

According to this result, when those with standardized score value higher than (0.513-0529) / $2=-0.008$ were classified as female and others as male, classification successes were obtained as in Table 3. The overall correct classification success of the new discriminant function containing a total of 4 angles $=(75+67) / 197=71.5 \%$. In addition, the sensitivity of the function (success in distinguishing female) was 68\% (68/100) and specificity (success in differentiating male) was $73.5 \%(73 / 97)$.

The ROC curve summarizing the diagnostic success of standardized discriminant scores is given below (Figure 4). The area under the ROC curve was found to be significant as $0.773 \pm 0.033(p<0.001)$.

Table 3: Prediction accuracy

\begin{tabular}{|c|c|c|c|c|}
\hline \multirow{2}{*}{ Gender } & \multicolumn{2}{|c|}{ Predicted group membership } & \multirow{2}{*}{ Total } & \multirow{2}{*}{$\begin{array}{c}\text { Accuracy } \\
\%\end{array}$} \\
\hline & Male & Female & & \\
\hline Male & 73 & 32 & 105 & $75.3 \%$ \\
\hline Female & 24 & 68 & 92 & $68 \%$ \\
\hline \multicolumn{5}{|c|}{ Overall Accuracy $71.5 \%$} \\
\hline
\end{tabular}

\section{DISCUSSION}

The skull is the part of the human skeleton that best reflects gender after the pelvis (11). Among the skull bones, the mandible has been used frequently in forensic studies because of its post-mortem resistance, being the largest and strongest (12). Because the mandible is movable part in the cranium, it should be evaluated alone in skeletal remains with impaired integrity and it plays a vital role in gender determination due to its sexual dimorphic characteristics $(10,19)$. While investigating the morphological features of the mandible, there are studies conducted on measurements made on dry mandible directly (20-22), on 2D images such as orthopantomography, cephalometric films $(2,6,23,24)$, and on $3 D$ imaging methods such as computed tomography (CT) and CBCT $(9,12)$. 2D images have limitations such as sharpness deterioration due to superposition and precision of the technique (13). By using CBCT images, these limitations can be overcome and measurements can be performed with sub-millimetric margin of error (12). In this study, the angular parameters of the mandible were measured using CBCT images and their usability in sexual prediction was evaluated.

Kim et al. (13) measured the Go angle in the frontal and sagittal planes and showed that there was no significant difference between the male and female genders and that the right Go angle values were higher. They concluded that there is asymmetry in the mandibular gonial region in the Korean population, with the right Go angle being greater for both gender. Similarly, Amin (12) stated in their study that the mean right Go angle was calculated higher and the reason for this might be due to the more use of the right side.

In this study, the mean Go angle values of the male on the right side and the left side of the female were found to be higher. Masseter muscle hyperactivity causes an increase in the rate of remodelling due to the increased load on the mandibular bone, and attachment of the masseter muscle to the gonial region may cause an increase in the size of this area and the Go angle (25). Chewing habits are affected by many factors such as the total occlusal contact area of the teeth and the number of teeth present (26). We think that the reason for these asymmetries in the gonial region is related to the chewing habits of the individuals.

When the studies comparing the Go angle between the genders were examined, although there were results that there was no statistically significant difference between the two genders $(3,13,27)$, and it was higher in male (9), many researchers found that it was higher in female $(8,12$, 28-31). Similarly, in our study, it was calculated that the left Go angle was statistically significantly higher in female and the left Go angle was the highest in distinguishing between male and female.

In a study investigating the direction of craniofacial growth in the period from late adolescence to late adulthood, (32) it was concluded that the mandibular growth direction differed between genders and that the mandibles of male had more forward rotation. This may be the reason why the Go angle is calculated lower in the male. In a study conducted with the same population as our study, the Go angle was examined in 50 female $\left(125.94 \pm 4.82^{\circ}\right)$ and 50 male $\left(124.86 \pm 7.16^{\circ}\right)$ individuals aged between $20-80$, and it was reported that there was no difference between genders ( $p>0.05)$ (19). In another study, it was reported that there is a difference between the genders in terms of right 
Go ( $p=0.014)$ and left Go ( $p=0.024)$ (33) When we compared these results with the average of the right Go angle, where no difference between genders was detected in our study, it was seen that the values were parallel. Although the average value of the left Go angle is high in males, it is not compatible with the results of Acar et al.(19) with its difference between genders. We think that these differences between studies may be caused by bilateral asymmetry due to the individuals using more than one side during chewing, although there are similar methods and studies conducted in the same population.

In our study, besides the left Go angle, the effect of right and left $\alpha$ angle and right $\beta$ angle on gender discrimination was found to be significant. All four angles were calculated to be statistically significantly higher in the female gender. In sagittal sections, lateral cephalometric view of the mandible, we measured $a$ and $\beta$ angles bilaterally in the triangle formed between $\mathrm{Co}$, Go and Gn points. $\alpha$ angle is between the height of the mandibular ramus and the edges of the mandibular length in this triangle. Decreasing the height of the mandibular ramus and/or increasing the mandibular body length will increase a angle. Linear measurements of previous studies showed that both ramus height and mandibular corpus length (body length) were calculated higher in male gender $(6,9,11,12)$. The size and morphology of the mandibular condyle and mandibular ramus have been found to be the most different regions between male and female, as they are remodelling centres during growth and development $(2,34,35)$. The more dominant difference in ramus height (mandibular height) between genders may be the reason why we found $a$ angle to be statistically significantly higher in female.

We think that the reason for the high right $\beta$ angle in female may be due to the different hyper function of the masticatory muscles on the dominant side of the masticatory function, depending on the gender, and the unilateral mechanical effect it exerts on the angular properties of the mandible.

When we examine the studies conducted by examining linear and angular parameters in the mandible; Kasar $\mathrm{H}$ et al. (36) found that, with the help of discriminant function analysis, it can predict gender with $83.1 \%$ accuracy in females, $76.47 \%$ in males and an overall accuracy $82 \%$ accuracy rate. In our study, the effect of discriminant function analysis on gender discrimination was found to be lower in females than males, and overall accuracy was $71.5 \%$. We think that the low level of this effect is due to the fact that there are variables that can discriminate gender and different discriminant functions that include variables.

When we examine studies conducted in different populations, overall accuracy is 60\% in a study conducted on 126 dry bones (3), $76 \%$ in a CT study (37) and $83.9 \%$ in a CT study conducted in an Egyptian population (38), in the other CT study, it was reported that gender prediction could be made with $90.8 \%$ accuracy by evaluating the for a complete mandible (39). Although these studies are in different populations, it has been reported that gender can be determined at a rate below and above our overall accuracy. We think that the most important effect in the change of these rates in gender determination is the sexual dimorphic feature of the parameters they examined and the excess number of parameters.

Gender assessment methods are considered to be useful if they produce at least $80 \%$ accuracy $(40)$. The fact that this rate was found to be $71.5 \%$ close to this value in our study contributes to the gender estimation process with the help of the angular parameters of the mandible.

In this study, it was observed that the left Go angle contributed the most in gender discrimination, and four of the ten angular parameters had a significant effect on gender discrimination. Although the accuracy rate determined in gender estimation is close to $80 \%$, this effect is low, indicating that angular parameters should be supported with linear measurements and proportions in order to obtain precise results in evaluating the mandible morphology for gender prediction. In addition, bilateral measurements due to mandibular asymmetries and taking into account on the dominant side will give more accurate results.

\section{Acknowledgment}

None.

\section{Author Contrubitons}

Project development, wrote and edited the manuscript: Seda Sertel Meyvacı, Collected and managed the data, wrote the manuscript: Duygu Göller Bulut, Ayşe Tuğçe Öztürk Koçak, Analysed the data and wrote the manuscript: Handan Ankaralı.

\section{Conflicts of Interest}

The authors declare that they have no conflict of interest.

\section{Financial Support}

No financial support was used for this study.

\section{Ethical Approval}

Ethical permission was obtained from Bolu Abant İzzet Baysal University Clinical Research Ethics Committee for the study with the decision number 2020/83.

\section{Review Process}

This article is published with blind-review process and extremely review. 


\section{REFERENCES}

1. Popa FM, Stefanescu CL, Corici PD. Forensic value of mandibular anthropometry in gender and age estimation. Rom J Leg Med 2009;17(1):45-50.

2. Indira AP, Markande A, David MP. Mandibular ramus: An indicator for sex determination - A digital radiographic study. J Forensic Dent Sci 2012;4(2):58-62.

3. Sharma M, Gorea RK, Gorea A, Abuderman A. A morphometric study of the human mandible in Indian populations for sex determination. Egypt J Forensic Sci 2016;6(2):165-169.

4. Robinson MS, Bidmos MA. The skull and humerus in the determination of sex: Reliability of discriminant function equations. Forensic Sci Int 2009;186(1-3):86. e1-86. e5.

5. Vinay G, Mangala Gowri SR, Anbalagan J. Sex determination of human mandible using metrical parameters. J Clin Diagn Res 2013;7(12):2671-2673.

6. Naikmasur VG, Shrivastava R, Mutalik S. Determination of sex in South Indians and immigrant Tibetans from cephalometric analysis and discriminant functions. Forensic Sci Int 2010;197(1-3):122. e1-122. e6.

7. Steyn M, Işcan MY. Metric sex determination from the pelvis in modern Greeks. Forensic Sci Int 2008;179(1):86. e1-86. e6.

8. Apaydın B, Icoz D, Yasar F, Akgunlu F. Evaluation of mandibular anatomical formation for gender determination in Turkish population. BJDM 2018;22(3):133-137.

9. Kharoshah MAA, Almadani O, Ghaleb S, Zaki MK, Fattah YAA. Sexual dimorphism of the mandible in a modern Egyptian population. J Forensic Leg Med 2010;17(4):213-215.

10. Kumar MP, Lokanadham S. Sex determination and morphometric parameters of human mandible. Int $\mathrm{J}$ Res Med Sci 2013;1(2):93-96.

11. Kallalli BN, Rawson K, Ramaswamy VK, Zakarneh WH, Singh A, Zingade J. Sex determination of human mandible using metrical parameters by computed tomography: A prospective radiographic short study. JIAOMR 2016;28(1):7.

12. Amin WM. Osteometric assessment of various mandibular morphological traits for sexual dimorphism in Jordanians by discriminant function analysis. J Morphol 2018;36(2):642-650.

13. Kim YH, Kang SJ, Sun H. Cephalometric angular measurements of the mandible using three-dimensional computed tomography scans in Koreans. Arch Plast Surg 2016;43(1):32.

14. Senn DR, Stimson PG. Forensic Dentistry. 2nd ed: CRC Press; 2010.

15. Scarfe WC, Farman AG. What is cone-beam CT and how does it work? Dent Clin North Am 2008;52(4):707-730.

16. Howerton WB, Mora MA. Advancements in digital imaging: What is new and on the horizon? J Am Dent Assoc 2008;139:S20-S24.

17. Hassan B, van der Stelt $P$, Sanderink G. Accuracy of three-dimensional measurements obtained from cone beam computed tomography surface-rendered images for cephalometric analysis: Influence of patient scanning position. Eur J Orthod 2009;31(2):129-134.

18. Nikneshan S, Aval SH, Bakhshalian N, Shahab S, Mohammadpour M, Sarikhani S. Accuracy of linear measurement using cone-beam computed tomography at different reconstruction angles. Imaging Sci Dent 2014;44(4):257-262.
19. Acar M, Alkan SB, Tolu I, Arslan FZ, Caglan F, Vermez H, Sasmaz S, Okutan S. Morphometric analysis of mandibula with mdct method in Turkish population. Asian $\mathrm{J}$ Biomed Pharmaceut Sci 2017;7(62):13.

20. Franklin D, O'Higgins P, Oxnard CE, Dadour I. Discriminant function sexing of the mandible of indigenous South Africans. Forensic Sci Int 2008;179(1):84. e1-84. e5.

21. Ongkana N, Sudwan P. Gender differences in Thai mandibles using metric analysis. Chiang Mai Med J 2009;48(2):43-48.

22. Datta A, Siddappa SC, Gowda VK, Channabasappa SR, Shivalingappa SB, Dey D. A study of sex determination from human mandible using various morphometrical parameters. Indian Journal of Forensic and Community Medicine 2015;2(3):158-166.

23. Thakur M, Reddy K, Sivaranjani Y, Khaja S. Gender determination by mental foramen and height of the body of the mandible in dentulous patients a radiographic study. Journal of Indian Academy of Forensic Medicine 2014;36(1):13-18.

24. Chandra A, Singh A, Badni M, Jaiswal R, Agnihotri A. Determination of sex by radiographic analysis of mental foramen in North Indian population. J Forensic Dent Sci 2013;5(1):52-55.

25. Seok H, Kim SG, Kim MK, Jang I, Ahn J. Effect of the masseter muscle injection of botulinum toxin $A$ on the mandibular bone growth of developmental rats. Maxillofac Plast Reconstr Surg 2018;40(1):1-8.

26. Meenakshi A, Paul P. Human chewing pattern: Prosthodontic Overview. International Journal of Oral Health and Medical Research 2017;4(1):80-85.

27. Shahabi M, Ramazanzadeh BA, Mokhber N. Comparison between the external gonial angle in panoramic radiographs and lateral cephalograms of adult patients with Class I malocclusion. J Oral Sci 2009;51(3):425-429.

28. Taleb NSA, Beshlawy ME. Mandibular ramus and gonial angle measurements as predictors of sex and age in an egyptian population sample: A digital panoramic study. Journal of Forensic Research 2015;6(5):1-7.

29. Xie QF, Ainamo A. Correlation of gonial angle size with cortical thickness, height of the mandibular residual body, and duration of edentulism. J Prosthet Dent 2004;91(5):477-482.

30. Rai R, Ranade AV, Prabhu LV, Pai MM, Madhyastha S, Kumaran M. A pilot study of the mandibular angle and ramus in indian population. International Journal of Morphology 2007;25(2):353-357.

31. Dutra V, Yang J, Devlin H, Susin C. Mandibular bone remodelling in adults: Evaluation of panoramic radiographs. Dentomaxillofac Radiol 2004;33(5):323-328.

32. Pecora NG, Baccetti T, McNamara JA. The aging craniofacial complex: A longitudinal cephalometric study from late adolescence to late adulthood. Am J Orthod Dentofacial Orthop 2008;134(4):496-505.

33. Apaydın B, Icoz D, Yasar F, Akgunlu F. Evaluation of mandibular anatomical formation for gender determination in Turkish population. Balkan Journal of Dental Medicine 2018;22(3):133137.

34. Humphrey LT, Dean MC, Stringer CB. Morphological variation in great ape and modern human mandibles. J Anat 1999;195(4):491-513. 
35. Franklin D, O'Higgins P, Oxnard CE, Dadour I. Determination of sex in South African Blacks by discriminant function analysis of mandibular linear dimensions. Forensic Sci Med Pathol 2006;2(4):263-268.

36. Kasar H, Çöloğlu AS, Kolusayin O. İskeletlerde altçene kemigi incelemeleri ile cinsiyet tayini. Journal of Forensic Medicine 1990;6(3-4):193-198.

37. Kallalli BN, Rawson K, Ramaswamy VK, Zakarneh WH, Singh A, Zingade J. Sex determination of human mandible using metrical parameters by computed tomography: A prospective radiographic short study. Journal of Indian Academy of Oral Medicine and Radiology 2016;28(1):7.
38. Kharoshah MAA, Almadani O, Ghaleb SS, Zaki MK, Fattah YAA. Sexual dimorphism of the mandible in a modern Egyptian population. J Forensic Leg Med 2010;17(4):213-215.

39. Tunis TS, Sarig R, Cohen H, Medlej B, Peled N, May H. Sex estimation using computed tomography of the mandible. Int $\mathrm{J}$ Legal Med 2017;131(6):1691-1700.

40. Rogers TL. A visual method of determining the sex of skeletal remains using the distal humerus. J Forensic Sci 1999;44(1):5760. 